УДК 343.1

DOI https://doi.org/10.32849/2663-5313/2020.12.39

\title{
Тимур Лоскутов,
}

докт. юрид. наук, доиент,

професор кафедри організачії досудового розслідування

Криворізького навчально-наукового інституту

Донецького юридичного інституту Міністерства внутрішніх справ України

\section{ОБМЕЖЕННЯ ТА ПОРУШЕННЯ ПРАВА НА СВОБОДУ ПІД ЧАС ПРОВЕДЕННЯ ОКРЕМИХ СЛІДЧИХ (РОЗШУКОВИХ) ДІЙ}

Стаття присвячується дослідженню питання щодо обмеження і порушення права на свободу під час проведення окремих слідчих (розшукових) дій. Аналізуються положення кримінального процесуального законодавства та практика кримінального провадження щодо обмеження права на свободу під час проведення окремих слідчих (розшукових) дій. Підкреслюється, що використання примусу є властивим прочесу проведення слідчих (розшукових) дій, а че вже може призводити до обмеження прав людини, зокрема порушення права особи на свободу. Відзначається, що у ході здійснення огляду, обшуку та пред'явлення особи для впізнання може обмежуватися свобода особи, яка не має кримінального прочесуального статусу, зокрема, конкретних прочесуальних прав і свобод для захисту від кримінального переслідування (обвинувачення). Виокремлюються формальний та змістовий підходи до визначення порушення права на свободу у перебігу здійснення деяких слідчих (розшукових) дій. Формальний підхід виявляється у тому, що момент фактичного обмеження свободи особи, ї̈ фізичного пересування ототожнюється із кримінальним проиесуальним затриманням, яке часто у практичній діяльності жодним чином не оформлюється. Змістовий (сутнісний) підхід щодо порушення права на свободу грунтується на практииі Європейського суду з прав людини, зокрема, на визначе них иим Судом критеріїв. Наголошується, що у разі користування сутнісним підходом до визначення порушення права на свободу особи під час проведення огляду, обшуку та пред'явлення особи для впізнання, то не завжди можна однозначно констатувати, що вказане право є неправомірно обмеженим органами кримінального судочинства. Підсумовується, що серед критеріїв порушення права особи на свободу у перебігу слідчих (розшукових) дій визначальне місие посідає такий критерій, як «наслідки». Зазначається, що коли наслідком здійснення слідчих (розшукових) дій є викриття особи, яка не має закріплених у законодавстві конкретних прав та свобод для свого захисту, навіть незначне обмеження свободи потрібно визнавати порушенням права людини на свободу. Визначаються перспективи подальших розвідок стосовно обмеження і порушення права на свободу під час здійснення прочесуальних дій.

Ключові слова: слідчі (розшукові) дії, огляд, обшук, пред’явлення для впізнання, обмеження свободи, порушення свободи.

Постановка проблеми. Одним із фундаментальних прав людини є право на свободу. Забезпечення цього права у межах кримінального провадження є особливо важливим. Оскільки внаслідок незаконного обмеження права на свободу можуть порушуватися інші права та свободи особи під час досудового та судового проваджень у кримінальному процесі. У зв'язку з цим дослідження питання щодо обмеження права на свободу під час проведення слідчих (розшукових) дій не може не бути актуальним нині.

Аналіз останніх досліджень та публікацій. Питання забезпечення права на свободу у кримінальному провадженні досліджувалося такими вченими, як: К.Д. Волков, І.В. Гловюк, О.В. Гончар, О.В. Капліна, Л.М. Лобойко,
П.М. Маланчук, А.О. Побережник, М.А. Погорецький, О.Г. Шило та інші. Проте науковці у своїх роботах не акцентували увагу на питанні обмеження права на свободу у ході здійснення слідчих (розшукових) дій.

Метою статті є дослідження питання щодо обмеження і порушення права на свободу під час проведення окремих слідчих (розшукових) дій. Для досягнення цієї мети були поставлені такі завдання, як: аналіз приписів процесуального законодавства та практики кримінального провадження щодо обмеження права на свободу під час проведення окремих слідчих (розшукових) дій; виокремлення підходів до визначення порушення права на свободу у перебігу здійснення вказаних дій. 
Виклад основного матеріалу. У теорії кримінального процесу забезпечення права на свободу насамперед розглядається щодо запобіжних заходів та заходів забезпечення кримінального провадження [1; 2]. Це $€$ цілком закономірним, оскільки застосування таких запобіжних заходів, як домашній арешт та тримання під вартою, безпосередньо пов'язане з обмеженням права особи на свободу під час кримінального процесу. Те ж саме можна зазначити і щодо заходів забезпечення кримінального провадження, котрі також реалізуються через обмеження свободи особи. Яскравим прикладом є застосування приводу та затримання особи за підозрою у скоєнні кримінального правопорушення. Таким чином, опрацювання питання стосовно обмеження права на свободу у ході реалізації заходів забезпечення кримінального провадження, у тому числі запобіжних заходів, $\epsilon$ прогнозованим та передбачуваним у кримінальній процесуальній доктрині. Застосування вказаних заходів здійснюється шляхом використання значного примусу, спрямованого на обмеження права на свободу особи у перебігу кримінального провадження.

Так однозначно, як щодо заходів забезпечення кримінального провадження, не можна вести мову про слідчі (розшукові) дії у контексті обмеження права на свободу. Тому що слідчі (розшукові) дії, на відміну від заходів забезпечення, спрямовані на одержання та перевірку доказової інформації. Таке призначення слідчих (розшукових) дій визначається як науковцями [3; 4], так і законодавцем (ч. 1 ст. 223 КПК) [5].

Разом із тим буде помилкою вважати, що слідчі (розшукові) дії здійснюються без використання жодного примусового впливу. Проведення слідчих дій може включати застосування примусу. Залежно від виду слідчої дії змінюється і характер примусу. Останній $є$ неоднаковим під час обшуку, виїмки, освідування порівняно з оглядом, допитом, призначенням експертизи [6, с. 104]. Тобто використання примусу є властивим процесу проведення слідчих (розшукових) дій, а це вже може призводити до обмеження прав людини, зокрема, порушення права особи на свободу.

Розглядаючи правову регламентацію окремих слідчих (розшукових) дій, можна відзначити, що деякі з них прямо передбачають застосування примусового впливу, що може стосуватися обмеження або навіть порушення права на свободу. Так, змістом ч. 3 ст. 241 КПК встановлюється можливість проведення примусового освідування у разі відмови особи здійснити його за добровільною згодою [5]. Аналогічним є нормативне положення щодо примусового відібрання у особи біологічних зразків для проведення експертизи [5].

Безумовно, що реалізація примусового освідування та примусового відібрання у особи біологічних зразків, як мінімум, буде зачіпати право особи на свободу, оскільки важко уявити примусовий огляд тіла людини та примусове отримання біологічних зразків у особи без обмеження її пересування.

Окрім того, нормами ч. 6 ст. 237 та ч. 3 ст. 236 КПК закріплюється право слідчого, прокурора щодо реалізації заборони будь-якій особі залишати місце огляду та обшуку до їх завершення [5]. Таким чином, цими законодавчими приписами слідчому, прокурору дозволяється обмежувати свободу пересування осіб, які беруть участь у проведенні огляду та обшуку.

До того ж можна навести таку слідчу (розшукову) дію, як пред’явлення особи для впізнання (ст. 228 КПК). Правове регулювання останнього хоча і прямо не передбачає застосування примусу, але він на практиці може проявлятися через підкорення особою наказу залишитися у певному місці або посісти конкретне місце поряд 3 іншими особами, які пред'являються для впізнання. У зазначений спосіб обмежується право на свободу особи, котра підлягає впізнанню.

Обмеження права на свободу під час примусового освідування та примусового відібрання у особи біологічних зрізків може відрізнятися від обмеження права на свободу під час проведення огляду, обшуку та пред’явлення особи для впізнання. Ця різниця полягає у наявності або відсутності у особи, свобода якої обмежується, кримінального процесуального статусу, зокрема, процесуальних прав і свобод для захисту від викривальної діяльності сторони обвинувачення. Якщо у перебігу примусового освідування та примусового одержання біологічних зразків у особи (яке проводиться за правилами освідування) [5] обмеження свободи може мати місце лише стосовно осіб у певному кримінальному процесуальному статусі (наприклад, свідок, підозрюваний, які мають відповідні права на правову допомогу та на захист (п. 2 ч. 1 ст. 66 КПК та п. 3 ч. 3 ст. 42 КПК)) [5], то у процесі реалізації огляду, обшуку та пред'явлення особи для впізнання може обмежуватися право на свободу особи, яка у кримінальному провадженні не має конкретного процесуального статусу. Отже, під час здійснення останніх слідчих (розшукових) дій обмежується свобода особи, яка не має ніяких процесуальних можливостей для захисту від кримінального переслідування (обвинувачення).

Якщо особа, яка впізнає, заздалегідь допитується у конкретному процесуаль- 
ному статусі, а значить на момент впізнання має відповідні права і свободи, то особа, яка пред'являється для впізнання, може не мати жодного процесуального статусу. Використаний термін «особа, яка підлягає впізнанню» не можна визнати правовим статусом особи у ході реалізації зазначеного засобу отримання відомостей, оскільки цей термін не передбачає наявність прав і свобод [7, с. 110]. Відповідно, у разі підкорення особою наказу залишитися у певному місці або посісти конкретне місце поряд з іншими особами, які пред'являються для впізнання, порушується право на свободу особи, яка не має кримінального процесуального статусу, а отже, прав і свобод для захисту від фактичної обвинувальної діяльності дізнавача, слідчого, прокурора.

Схожа ситуація можлива на практиці у разі застосування вищевказаних положень ч. 6 ст. 237 та ч. 3 ст. 236 КПК. Шляхом реалізації заборони щодо залишення будь-якою особою місця огляду та обшуку до їх завершення може порушувати право на свободу особи, яка не має чіткого процесуального статусу. Іншими словами, застосування цих кримінально-процесуальних положень КПК може стосуватися обмеження свободи особи, яка за приписами законодавства позбавлена процесуальних засобів стосовно захисту від обвинувачення.

Окрім того, треба відзначити, що з огляду на приписи ст. 209 КПК [5] особа у зазначених випадках обмеження свободи у ході здійснення огляду, обшуку та пред'явлення особи для впізнання має вважатися затриманою, а тому на неї має поширюватися кримінальний процесуальний статус підозрюваного з усіма процесуальними правами та свободами. Проте у практиці кримінального провадження за результатами застосування ч. 6 ст. 237 та ч. 3 ст. 236 КПК ніякий протокол про затримання не складається та особа, свобода якої обмежується, де-факто не користується процесуальними можливостями статусу підозрюваного. У цьому іноді можна вбачати порушення права людини на свободу під час кримінального провадження.

у Постанові Верховного Суду від 21 січня 2020 року описуються обставини, за яких органи досудового розслідування використали таку слідчу розшукову дію, як огляд місця події для обмеження свободи особи. Причому, як випливає зі змісту зазначеного рішення, органи кримінального судочинства ніякого протоколу про затримання не складали та процесуальні права підозрюваного не роз'яснювали. Тому Верховним Судом було констатовано істотне порушення кримінальних процесуальних приписів [8].
У цьому полягає формальний підхід до визначення порушення права на свободу особи під час здійснення процесуальних дій, у тому числі огляду, обшуку та пред'явлення для впізнання. Зазначений підхід виявляється у тому, що момент фактичного обмеження свободи особи, її фізичного пересування ототожнюється із кримінальним процесуальним затриманням, яке часто у практичній діяльності жодним чином не оформлюється.

Можна виокремити ще змістовий (сутнісний) підхід щодо обмеження права на свободу. Цей підхід грунтується на практиці Європейського суду з прав людини, відповідно до якої «позбавлення свободи» у значенні ст. 5 Конвенції про захист прав людини і основоположних свобод визначається з урахуванням конкретного становища особи. Для цього береться до уваги ціла низка критеріїв, зокрема, тип, тривалість, наслідки і спосіб виконання певного заходу (Рішення «Гуццарді проти Італії») [9].

Таким чином, якщо користуватися сутнісним підходом до визначення порушення права на свободу особи під час слідчих (розшукових) дій, наприклад, огляду, обшуку та пред'явлення особи для впізнання, то не завжди можна однозначно констатувати, що вказане право було неправомірно обмежене органами кримінального судочинства. Оскільки у разі, коли тривалість, наслідки та спосіб обмеження свободи особи у ході процесуальних дій (зокрема, такого типу, як слідчі (розшукові) дії) не були досить обтяжливими для особи та суттєво не впливають на її конкретне процесуальне становище, не можна вести мову про порушення у кримінальному провадженні права особи на свободу. Прикладом може бути застосування вищеописаної заборони щодо перебування на місці проведення огляду та обшуку до їх закінчення. Якщо часова тривалість здійснення зазначених слідчих (розшукових) дій є невеликою, спосіб обмеження свободи особи проявляється у висловленні та добровільному дотриманні відповідної заборони, а результатом здійснення огляду та обшуку не є викриття особи, свобода якої тимчасово обмежується, то у цій ситуації кримінального провадження важко визнати порушення права людини на свободу.

Вочевидь, у перебігу кримінального провадження можуть виникати обставини, за яких свобода особи має на деякий невеликий проміжок часу обмежуватися для з'ясування фактичних даних вчинення кримінального правопорушення. Не $є$ винятком окремі слідчі (розшукові) дії, внаслідок здійснення яких здобувається важлива кримінальна процесуальна інформація про кримінальне пра- 
вопорушення та особу, яка могла його скоїти. Разом із тим за критеріями тривалості, способу та наслідків обмеження свободи особи під час огляду та обшуку не є суворим (порівняно наприклад із обмеженням свободи під час застосування заходів забезпечення кримінального провадження), що у певних випадках унеможливлює констатацію порушення права людини на свободу. Хоча формально за нормами КПК особу, свобода якої тимчасово обмежується у ході слідчих (розшукових) дій, можна вважати затриманою.

Розглядаючи обмеження свободи під час здійснення слідчих (розшукових) дій, слід окремо зупинитися на такому критерії, як «наслідки». У контексті нашої тематики він є визначальним, оскільки інші критерії, а саме тип, тривалість та спосіб, є менш вагомими з огляду на природу самих по собі слідчих (розшукових) дій, котрі безпосередньо не є заходами примусу, а тому переважно тривалість та спосіб обмеження свободи у ході їх проведення $є$ не обтяжуючими для особи. Водночас зазначені, на перший погляд, незначні критерії обмеження свободи особи у ході здійснення огляду, обшуку, пред'явлення для впізнання можуть перетворитися на досить вагомі у поєднанні з критерієм наслідків. Бо якщо слідчі (розшукові) дії будуть спрямовані на викриття особи, свобода якої обмежується під час їх проведення, то навіть досить невелика тривалість та несуворий спосіб суттєво погіршують реальне становище відповідної особи. До того ж, як ми наголошували вище, особа, свобода якої обмежується у процесі здійснення огляду, обшуку, пред’явлення для впізнання, може не мати ніякого кримінального процесуального статусу, тобто жодних процесуальних інструментів для захисту від кримінального переслідування.

Беззаперечно, коли наслідком здійснення слідчих (розшукових) дій є викриття особи, яка не має закріплених у КПК конкретних прав для свого захисту, навіть незначне обмеження свободи потрібно визнавати порушенням права людини на свободу. Тому що за відсутності чітко визначеного у законодавстві процесуального положення особи, кримінальне переслідування останньої ставить iii у вразливе становище, котре погіршується далі більше, якщо свобода такої особи обмежується у межах реалізації слідчих (розшукових) дій. Тому за умови викривальної діяльності щодо особи, яка обмежується у свободі у ході слідчих (розшукових) дій, така особа має визнаватися затриманою за підозрою у вчиненні кримінального правопорушення та користуватися кримінальним процесуальним статусом підозрюваного з метою захисту від обвинувачення.

\section{Висновки}

Аналіз норм кримінального процесуального законодавства та практики кримінального провадження свідчить про те, що свобода особи може обмежуватися під час реалізації окремих слідчих (розшукових) дій. Причому особа, свобода якої обмежується, може не мати жодного кримінального процесуального статусу.

Порушення права на свободу під час проведення окремих слідчих (розшукових) дій (огляд, обшук, пред'явлення для впізнання) можна розглядати за формальним та змістовим (сутнісним) підходом.

Перспективами подальших розвідок у такому науковому напрямі можуть бути такі: розкриття питання щодо обмеження та порушення свободи у перебігу проведення інших слідчих (розшукових) дій; визначення особливостей обмеження і порушення свободи у ході реалізації заходів забезпечення кримінального провадження.

\section{Список використаних джерел:}

1. Гончар О.В. Застосування запобіжних заходів, які частково обмежують конституційне право особи на свободу пересування у кримінальному процесі України. Юридичний часопис Начіональної академії внутрішніх справ. 2013. № 2. С. 90-96.

2. Волков К. Забезпечення права на свободу та особисту недоторканність при затриманні особи. Вісник Національної академії прокуратури України. 2014. № 3. С. 108-112.

3. Журавель В.А. Слідчі (розшукові) дії як засоби формування доказів за чинним Кримінальним процесуальним кодексом України. Теорія та практика судової експертизи і криміналістики. 2013. Вип. 13. С. 22-30.

4. Пришляк С.О. Слідчі (розшукові) дії як засоби збирання доказів під час розслідування окремих кримінальних правопорушень. Науковий вісник Львівського державного університету внутрішніх справ. Серія юридична. 2013. Вип. 4. С. 417-427.

5. Кримінальний процесуальний кодекс України від 13 квітня 2012 року. URL: https://zakon. rada.gov.ua/laws/show/4651-17\#Text.

6. Лоскутов Т.О. Кримінальне переслідування, здійснюване слідчим : монографія. Дніпропетровськ : Ліра ЛТД, 2011. 164 с.

7. Лисаченко С.Л. Засоби отримання відомостей від особи у досудовому кримінальному провадженні : дис. ... канд. юрид. наук : 12.00.09. Харків : Національний юридичний університет імені Ярослава Мудрого, 2020. 249 с.

8. Постанова Верховного Суду від 21 січня 2020 року, справа № 756/8425/17, провадження № 51-859км19. URL: https://reyestr.court.gov.ua/ Review/87053575.

9. Рішення Європейського суду з прав людини «Гуццарді проти Італії». URL: http://hudoc. echr.coe.int/app/conversion/pdf?library=ECH R\&id $=001-105922 \&$ filename $=$ CASE $\% 200 F \% 20$ GUZZARDI\%20v.\%20ITALY\%20-\%20\%5B Ukrainian\%20Translation\%5D.pdf. 
Tymur Loskutov. Limitation and violation of the right to freedom when conducting individual investigative (search) actions

The article is devoted to the study of the issue of restriction and violation of the right to liberty during certain investigative (search) actions. The provisions of the criminal procedural legislation and the practice of criminal proceedings concerning the restriction of the right to liberty during the conduct of certain investigative (search) actions are analyzed. It is emphasized that the use of coercion is inherent in the process of conducting investigative (search) actions, and this can already lead to restrictions on human rights, in particularthe violation of a person's right to liberty. It is noted that during the inspection, search and presentation of a person for identification, the freedom of a person who does not have a criminal procedural status, in particular, specific procedural rights and freedoms to protect against criminal prosecution (prosecution) may be restricted. There are formal and substantive approaches to determining the violation of the right to liberty in the course of some investigative (investigative) actions. The formal approach is manifested in the fact that the moment of actual restriction of a person's freedom, his physical movement of a person is identified with criminal procedural detention, which is often not formalized in any way in practice. A substantive (substantive) approach to the violation of the right to liberty is based on the case law of the European Court of Human Rights, in particular, on the criteria set by this Court. It is emphasized that in the case of using an essential approach to determining the violation of the right to liberty of a person during the search, search and presentation of a person for identification, it is not always clear that this right is illegally restricted by criminal justice. It is concluded that among the criteria for violation of a person's right to liberty in the course of investigative (investigative) actions, such a criterion as "consequences" occupies a decisive place. It is noted that when the consequence of investigative (search) actions is to expose a person who does not have specific rights and freedoms enshrined in law for his protection, even a minor restriction of liberty should be recognized as a violation of the human right to liberty. Prospects for furtherinvestigation into the restriction and violation of the right to liberty in the course of proceedings are determined.

Key words: investigative (search) actions, inspection, search, presentation for identification, restriction of liberty, violation of liberty. 